\title{
Training, Knowledge Sharing, and Quality of Work-Life on Civil Servants Performance in Indonesia
}

\author{
Hasmin Tamsah ${ }^{1}$ \\ Sekolah Tinggi Ilmu Ekonomi Amkop, Makassar, Indonesia
}

Ansar

Sekolah Tinggi Ilmu Ekonomi Amkop, Makassar, Indonesia

Gunawan

Sekolah Tinggi Ilmu Ekonomi Amkop, Makassar, Indonesia

Yusriadi Yusriadi

Sekolah Tinggi Ilmu Administrasi Puangrimaggalatung, Makassar, Indonesia

Umi Farida

Sekolah Tinggi Ilmu Ekonomi Amkop, Makassar, Indonesia

\begin{abstract}
The research was conducted with the new public management paradigm; the community as the recipient of services is considered a customer. The study aims to reveal the relationship between training and employee performance in the public sector with knowledge sharing indicators as a mediator for both. This research uses a quantitative approach to SEM-Amos analysis tools. The sample was selected using a purposive sampling technique to the Civil Servants (CS) in an online questionnaire to participate in this study. The results showed that as many as 149 samples answered the questionnaire and had attended leadership training and other training. The results showed that the role of leadership training and additional training for training assessment tools to increase knowledge sharing was very influential compared to functional training, technical training, and other training. Although leadership training and further training significantly impact increasing knowledge sharing, they have not improved work-life and CS Performance quality. On the other hand, knowledge sharing shows an indirect effect on CS performance compared to its direct impact. Keywords: civil servants, Indonesia, knowledge sharing, performance, public institution, training.
\end{abstract}

The new public management paradigm in which public organizations organisations are perceived as profit organisations is the focus of this study. Public organisations have emphasised service to the community in the new public management concept, and bureaucratic leaders were perceived as company leaders. Increasing productivity and finding alternatives or ways of available service based on an economic perspective.

Leaders of public organisations are encouraged to improve and realise public accountability, improve performance, restructuring, public bureaucratic institutions, redefine

\footnotetext{
${ }^{1}$ Corresponding author e-mail: hasmintamsah@gmail.com
} 
organisational mission, bureaucratic procedures, and decentralise the policy return process (Peters \& Peters, 2018).

Public organisations that are operated with the new public management paradigm have implications for all Civil State Apparatus (CSA) activities when perceived as employee activities in private organisations. From this perspective the activities carried out by the CSA can be analysed from the viewpoint of human capital theory. The comprehensive approach of human capital theory posits that improving the welfare of society requires, everyone was to increase productivity. The most recent viewpoint of human capital focuses on the skills and all the characteristics of individual employees as assets for companies that will increase productivity (Gennaioli et al., 2013; Nguye, 2020).

A variety of techniques are used by organisations to enhance the efficiency of civil servants. One such approach is the introduction of information exchange. That if someone has more expertise and can process it effectively, it would affect state employees' performance outcomes by introducing information sharing with the government. It is hoped that the output of civil servants would improve. Factors influencing the professional environment have now moved to the information age (Cabrera \& Cabrera, 2002). It is currently a "knowledge digitization" so that only organizations that can process knowledge optimally can survive in the context of global competition (Gagné, 2009). The benefits received are the sharing of expertise, quality, and innovation.

Knowledge exchange is a solution for enhancing efficiency, and it has a beneficial impact. However, the execution needs high-quality human capital to allow knowledge sharing to run based on organizational expectations (Hansen et al., 2005; Kilinc, 2014; Pena et al., 2018). Training impacts the exchange of information, organisations must have instruction, and it enhances human capital by developing knowledge-sharing networks (Kamaşak \& Bulutlar, 2010). The government should be able to monitor civil servants' information so that they are kept up to date with innovations. Considering the findings, the government has encouraged civil servants to train, as shown by the introduction of information sharing for each civil servant after completing skills training (Sri Wahyu Lelly Hana Setyanti, 2013).

The success of the organisational performance is measured by the increase in the performance of the agency. Performance improvement can be realized if the management is good, encouraging the agency's efforts to improve performance. Training, knowledge sharing is a tool that can be used to improve civil servants' performance in public sector organizations (Gagné, 2009). Every human being manages himself in today's digitalization era, namely with new strategies, new tools, methods, and new processes. Organizations are required to have quality human resources, innovations, and knowledge to face competition (Xue et al., 2011). Performance improvement is supported by training, knowledge sharing, and work quality in organizations. Previous research, showing that successful implementation requires integration, namely leadership, learning, organizational structure, and technology (Lord, 2006); this factor is a tool to improve the performance of both public and private organizations.

The general principles of performance improvement implemented within the government are in the form of a culture of knowledge sharing and carried out in the government environment, specifically through the culture of one day one information. This culture is intended to encourage civil servants to seek flattering details and share it with other employees to become shared knowledge. The training that is often carried out is also a strong reason that performance improvements have long existed and been applied in government circles.

Based on the description above, empirical studies related to the application of training, knowledge sharing, and the implications of achieving civil servants' performance in government circles are essential to do. This is based on the consideration that knowledge management is something new in public organizations in Indonesia. An organization needs to see that a new system or administration can be accepted and works well as expected, so it is necessary to answer problems that arise about implementing knowledge management on employee 
performance.

Therefore, this study was conducted to analyse the effect of training, knowledge sharing, and work quality on civil servants' performance. Knowledge management indicators used in this study refer to indicators developed by Alavi and Leidner (2001), Gao et al. (2008), and Gold et al. (2001). This indicator was chosen as the knowledge management model studied because it was believed that this indicator could represent the condition of the knowledge management system currently being implemented in the government environment. These indicators have been empirically applied in previous research and produce implications or recommendations for good research results.

This study is different from previous studies because this study examines the indicators of implementing knowledge management on performance in Indonesia's government; this has not been found in previous studies. This study also uses ordinal to interval conversion data; the data conversion was not carried out in previous studies. Academically, this research is expected to provide empirical evidence about the impact of knowledge management in government on employee performance achievement. This research is also likely to add further research references for apparatus resource management, mainly related to knowledge management in public sector organizations. In practical terms, this study's results are expected to become material for consideration for policyholders associated with the implementation of organizational knowledge management policies, especially in the public sector.

\section{Literature Review}

Employee performance could develop better if employees try to improve their capabilities. A civil servant should be able to arrange his or her career planning early on. Thus, civil servants must try to increase their ability to engage self-development. Self-development of an employee can be performed in two ways through, long-term education and training. This study focused on developing employee skills through training (Kilinc, 2017; Houdyshell \& Kirk, 2018). Several experts have tested various concepts related to training, which can improve the ability of employees. However, this study is devoted to public sector employees, namely, those of the civil servants.

Various studies have discussed training and its, relationship with improving employee performance and knowledge sharing. Both routine and incidental training are believed to have a relationship with knowledge sharing. The more training conducted by civil servant, then the greater opportunity for civil servants to conduct knowledge sharing. Training could improve employee skills, which, in turn, can improve performance (A et al., 2019; Mustafa et al., 2020; Rijal et al., 2019). Thus, the following hypothesis is posited.

H1: Training will have a significant and positive effect on knowledge sharing.

Knowledge sharing is in helping organisations expand information, new procedures, and new ways or methods. The classic problem in public organisations is that the budget allocated for civil servant's capacity building through training is minimal. Therefore, a model that can maximise the benefits of limited training is required. This study created a model that placed knowledge sharing between training as an input (Umar, Hasbi, et al., 2019) and civil servant performance as output. The objective was to determine if knowledge sharing can maximise the benefits gained from limited training and improve civil servant performance (Miller, 2018; Ramseook-Munhurrun et al., 2010).

Some research has shown that knowledge sharing could increase individual creativity (Cabrera \& Cabrera, 2002). Based on this concept, the following hypothesis is posited. 
H2: Knowledge sharing will have a significant and positive effect on civil servant performance

Knowledge sharing is part of knowledge management, which can improve the quality of work-life in the public sector (Gagné, 2009). Increased knowledge sharing about work could improve the quality of work-life, which, in turn, leads to an increase in employee performance (Darroch, 2005).

In this context, the better the application of knowledge sharing in an organisation, then the better the quality of work life. This relationship could be because knowledge disseminated to all employees can trigger their general and specific knowledge of their work so that the quality of work-life will be better (Earl, 2001). Based on these relationships, the following hypothesis.

H3: Knowledge sharing will have a significant and positive effect on the quality of work-life.

Quality of work life plays a large role in the creation of employee performance, both in the public and private sectors. Conceptually, a person who has a good quality of work-life will more easily accept a good job so that the performance will improve (Rubenstein-Montano et al., 2001). Quality of work life can also encourage employee productivity (Gagné, 2009). In addition, quality of work-life can also encourage someone's willingness to change (Rowley, 1999), which can enhance work creativity and employee performance further. Studies on quality of work-life also showed that the better quality of work-life of an employee will increase employee creativity, flexibility, which ultimately improves the performance (Inkpen \& Tsang, 2005). Based on the concepts built from the results of previous studies, the following hypothesis can be made.

H4: Quality of work-life will have a significant and positive effect on civil servant performance.

\section{Methodology}

This research used a quantitative approach using a survey among conducted with subjects from civil servant, which, was distributed online to four months during the period from April to July. The minimum sampling target was 200 people returning early because SEMAMOS, which was the software uses, works well with 100-200 respondents (Byrne, 2013). SEM-AMOS offers several advantages over other analytical tools, including enabling more flexible assumptions, using confirmatory factor analysis to minimise measurement errors by having multiple indicators in one latent variable, and allowing testing of the overall model of the coefficients in an overall individually (Byrne, 2013). A total of 200 surveys were received, but only 149 completed questionnaires were included in the data analysis.

The results showed that 149 respondents had participated in leadership training and other training programs, 159 respondents had participated in functional and other training programs, and 155 respondents had attended technical training and other training programs.

The variables in this study were measured using a Likert-type scale ranging from 1 to 5 in which 1 indicated strong disagreement and 5 indicated show strong agreement with the statement. The questionnaire statements were built from previous studies. This study examined the activities carried out either programmed or incidentally based on the needs of the organisation or individual in connection with their duties and responsibilities. The training activities in the framework of increasing ASN competence were divided into two activities, namely, pre-service activities and in-office activities. Furthermore, training in positions were divided into three: leadership training, functional training, and technical training. The training indicators used to refer to (Alavi \& Leidner, 2001; Gao et al., 2008; Gold et al., 2001) namely, 1) having what you need to do your job; 2) the content of a relevant course; 3) suitable facilities 
for teaching and learning, and 4) does not duplicate what you learned previously.

Indicator of knowledge sharing (Gao et al., 2008), included 1) sense of self-worth; 2) face concern; 3) general knowledge sharing; and 4) specific knowledge sharing. The work-life quality variable also used developed indicators from previous studies. Indicators of work-life quality (Denhardt \& Denhardt, 2000), were 1) work environment-related aspects; 2) management related aspects; 3) social aspects; 4) economic aspects, and 5) job-related aspects.

Then the civil servant's performance variables were adopted from the results of previous studies (Hasbi et al., 2020; Rahawarin et al., 2020). These included, two dimensions, namely, a quantitative dimension, and the qualitative dimension. Indicators for measuring employee performance were: 1) quantity (work targets, project deadlines, limited resources); 2) new ideas, errors at work, time, utilization.

\section{Analysis and Interpretation of the Research Results}

This research examined three different conceptual models of the education and training variables in influencing civil servant performance through knowledge sharing and quality of work life. The three conceptual models were conceptual model measures training with two types of training, namely leadership training and other training. The second conceptual model use functional training and further training, while the third conceptual model used technical training and additional training as a marker of education and training.

Model test results with confirmatory factor analysis on each variable indicated that all indicators were used. The threshold for each loading factor was greater than 0.4 and a C.R. of greater than 2.0 (Teece et al., 2009). The significance tests for each factor were met (see Tables $1-3)$.

Table 1

Factor Loadings Model 1

\begin{tabular}{lllcccccc}
\hline & & & $\begin{array}{c}\text { Standardised } \\
\text { Estimate }\end{array}$ & Estimate & S.E. & C.R. & P & Label \\
\hline PSP2 & $<---$ & PSP & $\underline{.973}$ & 2.028 & .389 & 5.212 & $* * *$ & par_13 \\
PSP1 & $<---$ & PSP & $\underline{.976}$ & 1.000 & & & & \\
TRN4 & $<---$ & TRN & $\underline{.805}$ & 1.000 & & & & \\
TRN1 & $<---$ & TRN & $\underline{.620}$ & .766 & .130 & 5.877 & $* * *$ & par_1 \\
KSN4 & $<---$ & KNS & $\underline{.798}$ & 1.000 & & & & \\
KSN3 & $<---$ & KNS & $\underline{.816}$ & .907 & .085 & 10.708 & $* * *$ & par_2 \\
KSN2 & $<---$ & KNS & $\underline{.625}$ & .893 & .125 & 7.168 & $* * *$ & par_3 \\
KSN1 & $<---$ & KNS & $\underline{.665}$ & .667 & .090 & 7.414 & $* * *$ & par_4 \\
QWL1 & $<---$ & QWL & $\underline{.752}$ & 1.000 & & & & \\
QWL2 & $<---$ & QWL & $\underline{.867}$ & 1.571 & .148 & 10.607 & $* * *$ & par_5 \\
QWL3 & $<---$ & QWL & $\underline{.705}$ & .756 & .090 & 8.389 & $* * *$ & par_6 \\
QWL4 & $<---$ & QWL & $\underline{.500}$ & .749 & .129 & 5.813 & $* * *$ & par_7 \\
QWL5 & $<---$ & QWL & $\underline{.611}$ & .972 & .140 & 6.947 & $* * *$ & par_8 \\
PSP1.1 & $<---$ & PSP1 & $\underline{.529}$ & 1.000 & & & & \\
PSP1.2 & $<---$ & PSP1 & $\underline{.807}$ & 1.365 & .233 & 5.862 & $* * *$ & par_9 \\
PSP1.3 & $<---$ & PSP1 & $\underline{.697}$ & 1.188 & .215 & 5.533 & $* * *$ & par_10 \\
PSP2.1 & $<---$ & PSP2 & $\underline{.724}$ & 1.000 & & & & \\
PSP2.2 & $<---$ & PSP2 & $\underline{.745}$ & .941 & .113 & 8.294 & $* * *$ & par_11 \\
PSP2.3 & $<---$ & PSP2 & $\underline{.781}$ & .878 & .104 & 8.407 & $* * *$ & par_12 \\
\hline
\end{tabular}


Note. PSP: public servant performance; TRN: training; KSN: knowledge sharing; QWL: quality of work-life.

Table 1 shows that the indicators of all variables in the first model had a loading factor of more than 0.4 (Moenir, 2010). Thus, these indicators serve as markers of the variables in this study. In the first model, training is measured by indicators of leadership training and other training (training other than leadership, functional, and technical).

Table 2

Loading Factors Loadings Model II

\begin{tabular}{|c|c|c|c|c|c|c|c|c|}
\hline & & & $\begin{array}{l}\text { Standardised } \\
\text { Estimate }\end{array}$ & Estimate & S.E. & C.R. & $\mathrm{P}$ & Label \\
\hline PSP2 & $<---$ & PSP & $\underline{1.008}$ & 1.942 & .348 & 5.574 & $* * *$ & par_13 \\
\hline PSP1 & $<---$ & PSP & .976 & 1.000 & & & & \\
\hline TRN4 & $<---$ & TRN & .785 & 1.000 & & & & \\
\hline TRN2 & $<---$ & TRN & .680 & .713 & .124 & 5.770 & $* * *$ & par_1 \\
\hline KSN4 & $<---$ & KNS & .841 & 1.000 & & & & \\
\hline KSN3 & $<---$ & KNS & .806 & .811 & .069 & 11.787 & $* * *$ & par_2 \\
\hline KSN2 & $<---$ & KNS & .604 & .885 & .116 & 7.610 & $* * *$ & par_3 \\
\hline KSN1 & $<---$ & KNS & .606 & .571 & .077 & 7.438 & $* * *$ & par_4 \\
\hline QWL1 & $<---$ & QWL & .691 & 1.000 & & & & \\
\hline QWL2 & $<---$ & QWL & .848 & 1.585 & .167 & 9.494 & $* * *$ & par_5 \\
\hline QWL3 & $<---$ & QWL & .788 & .943 & .106 & 8.887 & $* * *$ & par_6 \\
\hline QWL4 & $<---$ & QWL & .424 & .658 & .132 & 4.966 & $* * *$ & par_7 \\
\hline QWL5 & $<---$ & QWL & .694 & 1.088 & .140 & 7.754 & $* * *$ & par_8 \\
\hline PSP1.1 & $<---$ & PSP1 & .503 & 1.000 & & & & \\
\hline PSP1.2 & $<---$ & PSP1 & .817 & 1.342 & .226 & 5.940 & $* * *$ & par_9 \\
\hline PSP1.3 & $<---$ & PSP1 & .766 & 1.265 & .218 & 5.817 & $* * *$ & par_10 \\
\hline PSP2.1 & $<---$ & PSP2 & .715 & 1.000 & & & & \\
\hline PSP2.2 & $<---$ & PSP2 & .720 & .936 & .108 & 8.646 & $* * *$ & par_11 \\
\hline PSP2.3 & $<---$ & PSP2 & .774 & .962 & .106 & 9.072 & $* * *$ & par_12 \\
\hline
\end{tabular}

Note. PSP: public servant performance; TRN: training; KSN: knowledge sharing; QWL: quality of work-life.

Table 2 also shows that the indicators of all variables in the first model had a loading factor of more (Moenir, 2010). Thus, these indicators serve as markers of the variables in this study. In the second model, training is measured by indicators of functional training and other training (training other than leadership, functional, and technical).

In line with Tables 1 and 2, Table 3 also shows that the indicators of all variables in the first model had a loading factor or more than 0.4 (Moenir, 2010). Thus, these indicators serve as markers of the variables in this third model. In the third model, where training is measured by indicators of technical training and other training (training other than leadership, functional, and technical).

Thus, all variables can be measured by the indicators used in the three models studied. However, the final model test results on the three concepts (Models 1-3) studied had differences in each variable that are presented in the following results. 
Table 3

Loading Factors Model III

\begin{tabular}{|c|c|c|c|c|c|c|c|c|}
\hline & & & $\begin{array}{l}\text { Standardised } \\
\text { Estimate }\end{array}$ & $\begin{array}{l}\text { Estim } \\
\text { ate }\end{array}$ & S.E. & $\begin{array}{c}\text { C.R } \\
.\end{array}$ & $\mathrm{P}$ & $\begin{array}{c}\text { Labe } \\
1\end{array}$ \\
\hline PSP2 & $<-$ & PSP & .960 & 1.616 & .260 & 6.208 & $* * *$ & par_13 \\
\hline PSP1 & $<-$ & PSP & 1.035 & 1.000 & & & & \\
\hline TRN4 & $<-$ & TRN & .900 & 1.000 & & & & \\
\hline TRN3 & $<-$ & TRN & .565 & .672 & .150 & 4.483 & $* * *$ & par_1 \\
\hline KSN4 & $<--$ & KNS & .812 & 1.000 & & & & \\
\hline KSN3 & $<--$ & KNS & .836 & .889 & .083 & $\begin{array}{c}10.68 \\
2\end{array}$ & $* * *$ & par_2 \\
\hline KSN2 & $<--$ & KNS & .626 & .969 & .124 & 7.786 & $* * *$ & par_3 \\
\hline KSN1 & $<--$ & KNS & .537 & .555 & .085 & 6.551 & $* * *$ & par_4 \\
\hline QWL1 & $<--$ & QWL & .746 & 1.000 & & & & \\
\hline QWL2 & $<--$ & QWL & .836 & 1.479 & .149 & 9.935 & $* * *$ & par_5 \\
\hline QWL3 & $<--$ & QWL & .698 & .774 & .093 & 8.331 & $* * *$ & par_6 \\
\hline QWL4 & $<--$ & QWL & .428 & .601 & .119 & 5.032 & $* * *$ & par_7 \\
\hline QWL5 & $<--$ & QWL & .604 & .887 & .124 & 7.170 & $* * *$ & par_8 \\
\hline PSP1.1 & $<--$ & PSP1 & .567 & 1.000 & & & & \\
\hline PSP1.2 & $<--$ & PSP1 & .748 & 1.146 & .169 & 6.790 & $* * *$ & par_9 \\
\hline PSP1.3 & $<--$ & PSP1 & .652 & .991 & .159 & 6.233 & $* * *$ & par_10 \\
\hline PSP2.1 & $<--$ & PSP2 & .710 & 1.000 & & & & \\
\hline PSP2.2 & $<--$ & PSP2 & .703 & .940 & .119 & 7.881 & $* * *$ & par_11 \\
\hline PSP2.3 & $<--$ & PSP2 & .718 & .842 & .105 & 8.040 & $* * *$ & par_12 \\
\hline
\end{tabular}

Note. PSP: public servant performance; TRN: training; KSN: knowledge sharing; QWL: quality of work-life.

Figure 1

Conceptual Model 1

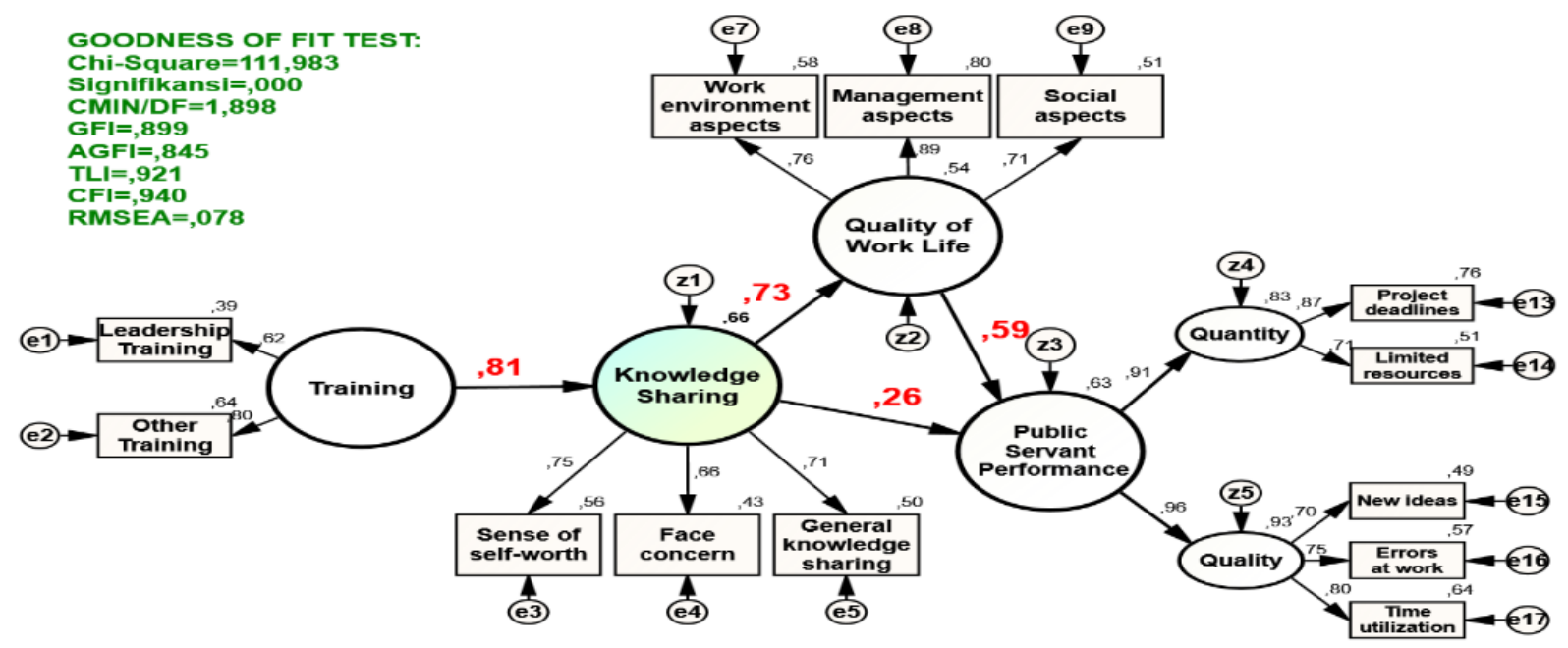

The results of hypothesis test 1 are shown in the first conceptual model (Figure 1) through the SEM-AMOS test. In the first model, training was measured by two types of training, 
namely, leadership training and other training. The final model produced in this study had a goodness of fit as indicated by CMIN / DF $=1.90 ; \mathrm{GFI}=0.90 ; \mathrm{AGFI}=0.85 ; \mathrm{TLI}=0.92 ; \mathrm{CFI}$ $=0.94 ;$ RMSEA $=0.08$. Because several criteria, CMIN / DF $(1.90 \leq 2.00)$ and RMSEA $(0.08 \leq 0.80)$, corresponded with the view (Ruslan, Rosady, SH, 2014), the model is considered good.

Table 4

The Relationship Between Variables and the Estimation Results of Conceptual Model 1

\begin{tabular}{lcccc}
\hline \multicolumn{1}{c}{ Variable Relationship } & Estimate & C.R & P & Note \\
\hline Training $\rightarrow$ Knowledge sharing & 0,813 & 5,703 & $* * *$ & Supported \\
Knowledge sharing $\rightarrow$ Quality of Work & 0,732 & 6,722 & $* * *$ & Supported \\
$\begin{array}{l}\text { Life } \\
\text { Quality of Work Life } \rightarrow \text { Civil Servants }\end{array}$ & 0,586 & 3,813 & $* * *$ & Supported \\
$\begin{array}{l}\text { Performance } \\
\text { Knowledge sharing } \rightarrow \text { Civil Servants }\end{array}$ & 0,260 & 1,837 & 0,066 & Not Supported \\
Performance
\end{tabular}

One interesting thing from this first conceptual model was that the training measured by the type of leadership training and other training had a greater influence through knowledge sharing then the quality of work-life and then to civil servants' performance. This was better than if the effect was through knowledge sharing to civil servants' performance (the effect was not significant). These results indicated that training (leadership training and other training) would be maximally beneficial with knowledge sharing. Knowledge sharing itself was not enough, but it was better with the quality of work-life than directly to civil servants' performance (more complete results presented in Table 1).

\section{Figure 2}

Conceptual Model 2

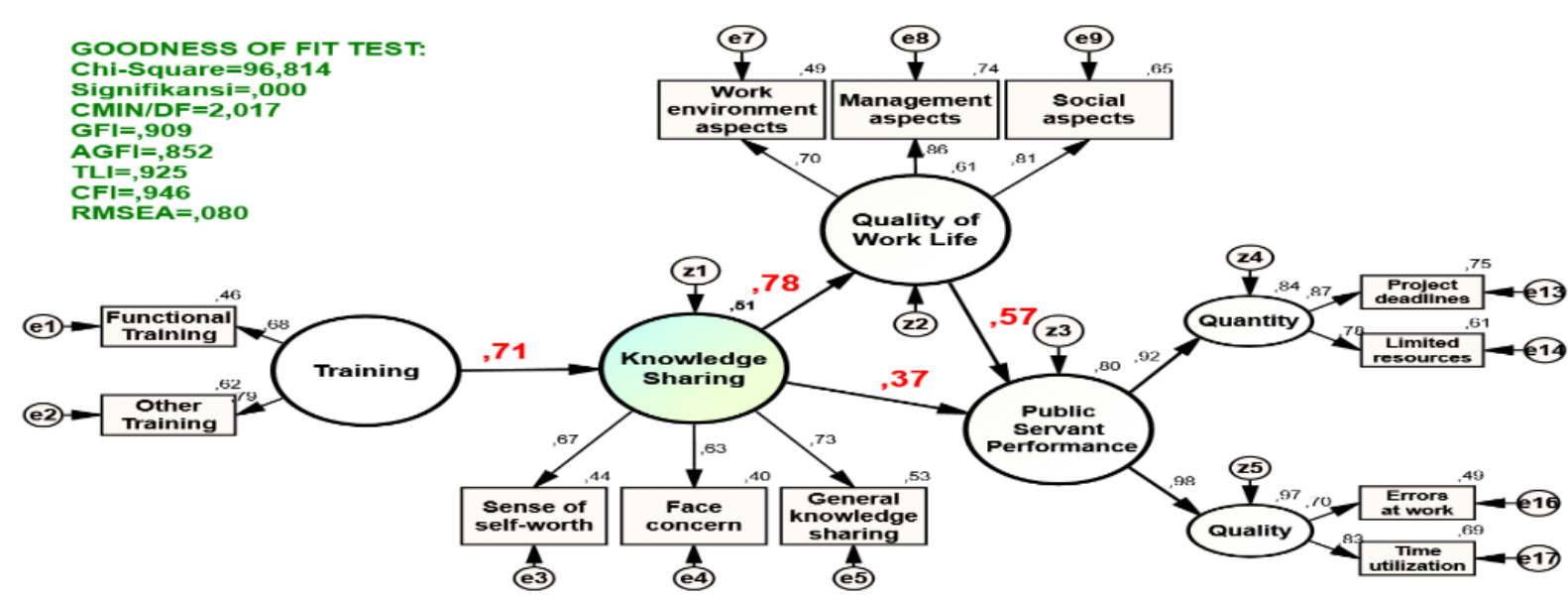

For hypothesis test 1 , the first conceptual model shown in Table 1 that the training measured by indicators of leadership training and other training had a significant effect on knowledge sharing $(C R=5.703 ; P=0.000)$, then knowledge sharing had a significant effect on the quality of work-life $(\mathrm{CR}=6,722 ; \mathrm{P}=0,000)$ while the effect on ASN Performance was not significant $(\mathrm{CR}=1,837 ; \mathrm{P}=0.066)$. Further results found that the quality of work-life had a significant effect on ASN Performance (C.R = 3,813; $\mathrm{P}=0,000)$. This result showed that more training conducted by ASN, the greater opportunity to do knowledge sharing (Dalkir, 2011). Furthermore, knowledge sharing, which was part of knowledge management, could improve 
the quality of work-life in the public sector (Davenport et al., 1998). In addition, training improves employee skills, which can further improve performance (Phelps et al., 2012).

Hypothesis 2 test results on the second conceptual model are shown in Figure 2 through the SEM-AMOS test. In this model, training was measured by two types of training, namely, functional training and other training. The final model produced in this study had a goodness of fit as indicated by CMIN / DF $=2.02$; GFI $=0.91$; AGFI $=0.85 ; \mathrm{TLI}=0.93 ; \mathrm{CFI}=0.95$; RMSEA $=0.08$. Therefore, several criteria that meet mainly GFI $(0.91 \geq 0.90)$, CFI $(0.95 \geq 0.95)$, and RMSEA $(0.08 \leq 0.08)$ corresponded with the view of (McInerney, 2002) and then this model was considered good and fulfils the requirements.

Table 5

The Relationship Between Variables and the Estimation Results of Conceptual Model 2

\begin{tabular}{lcccc}
\hline \multicolumn{1}{c}{ Variable Relationship } & Estimate & C.R & P & Note \\
\hline Training $\rightarrow$ Knowledge sharing & 0,714 & 5,033 & $* * *$ & Supported \\
Knowledge sharing $\rightarrow$ Quality of Work Life & 0,779 & 5,968 & $* * *$ & Supported \\
Quality of Work Life $\rightarrow$ ASN Performance & 0,574 & 3,908 & $* * *$ & Supported \\
Knowledge sharing $\rightarrow$ ASN Performance & 0,373 & 2,570 & 0,010 & Supported \\
\hline
\end{tabular}

The interesting thing from this second conceptual model was the training measured by the type of functional training, and other training would have greater influence through knowledge sharing then the quality of work-life and then to ASN performance. This was better if the effect was through knowledge sharing to ASN performance even though in this conceptual model, the effects were all significant. These results indicated that training (functional training and other training) would be maximally beneficial with knowledge sharing. Knowledge sharing itself was not enough, but it was better if through the quality of work-life than directly to ASN performance (Table 2).

Figure 3

Conceptual Model 3

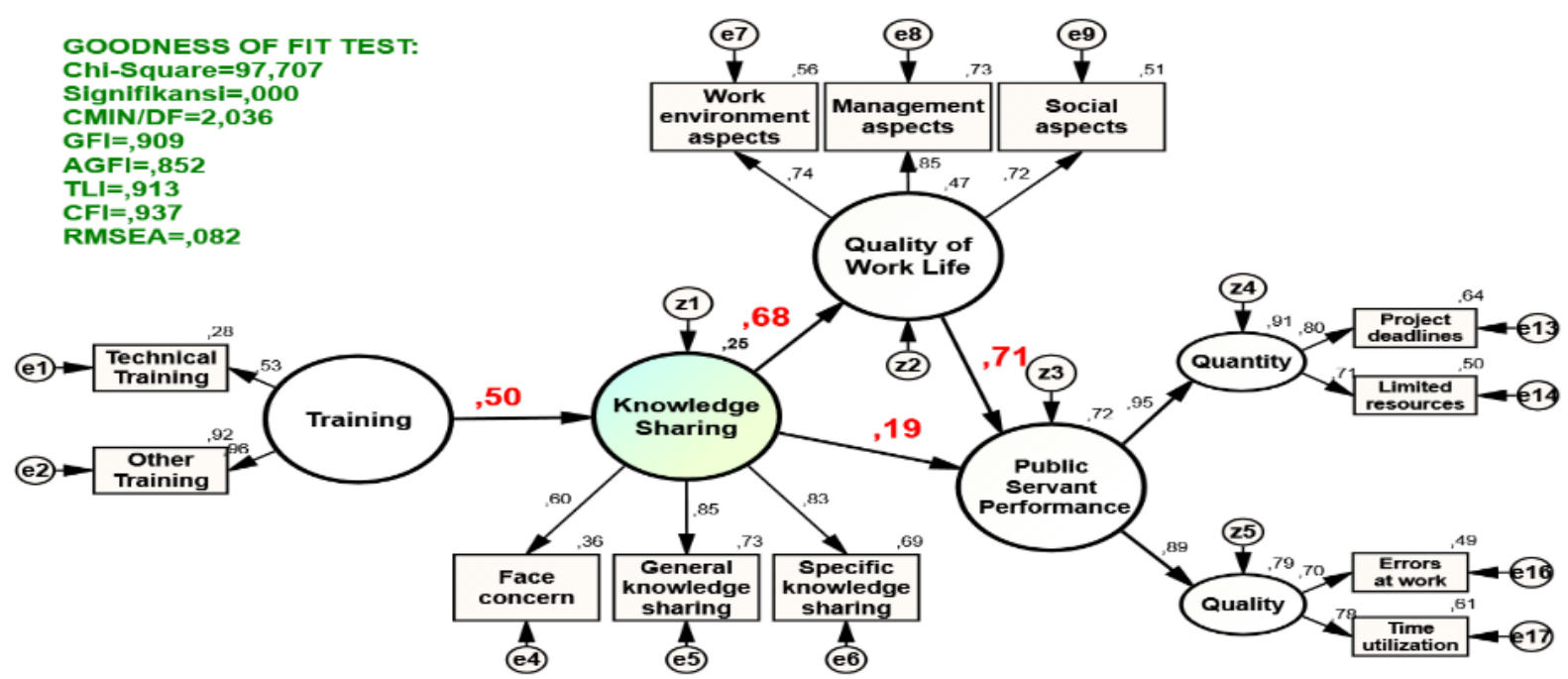

For testing hypothesis 2 in the second conceptual model as shown in Table 2, the training measured by functional training and other training indicators provides different findings compared to the first model, where knowledge sharing actually had a significant effect 
on ASN Performance $(\mathrm{CR}=2,570 ; \mathrm{P}=0.010)$. The other findings had the same implication that training had a significant effect on knowledge sharing $(C R=5,033 ; \mathrm{P}=0,000)$, then knowledge sharing had a significant effect on quality of work-life $(C R=5.968 ; P=0,000)$, and quality of work-life had an effect significant on ASN Performance $(\mathrm{CR}=3,908 ; \mathrm{P}=0,000)$. These results confirm previous results that knowledge sharing will improve the quality of worklife (Ermine, 2010). Furthermore, someone who had a good quality of work-life would more easily accept a good job so that performance would improve (Hyland \& Soosay, 2008).

The results of hypothesis test 3 on the third conceptual model are shown in Figure 3 through the SEM-AMOS test with training was measured by two types of training, namely technical training, and other training. The final model produced in this study had a goodness of fit as indicated by $\mathrm{CMIN} / \mathrm{DF}=2.04$; $\mathrm{GFI}=0.91 ; \mathrm{AGFI}=0.85 ; \mathrm{TLI}=0.91 ; \mathrm{CFI}=0.94 ; \mathrm{RMSEA}$ $=0.08$. Because several criteria that meet mainly GFI $(0.91 \geq 0.90)$ and RMSEA $(0.08 \leq 0.08)$ corresponded with the view (Van De Ven \& Johnson, 2006), then this model is considered good and qualified.

\section{Table 6}

The Relationship Between Variables and the Estimation Results of Conceptual Model III

\begin{tabular}{lcccc}
\hline \multicolumn{1}{c}{ Variable Relationship } & Estimate & C.R & P & Note \\
\hline Training $\rightarrow$ Knowledge sharing & 0,500 & 3,353 & $* * *$ & Supported \\
Knowledge sharing $\rightarrow$ Quality of Work Life & 0,683 & 6,809 & $* * *$ & Supported \\
Quality of Work Life $\rightarrow$ ASN Performance & 0,709 & 5,018 & $* * *$ & Supported \\
Knowledge sharing $\rightarrow$ ASN Performance & 0,190 & 1,645 & 0,100 & Not \\
& & & & Supported \\
\hline
\end{tabular}

In the third conceptual model, training was measured by the type of technical training and other training would be greater influence through knowledge sharing, then the quality of work-life influences the ASN performance. This was better than if the effect through knowledge sharing to ASN performance and, in this conceptual model, the effect was not significant (same as the first conceptual model). These results indicated that training (technical training and other training) would be maximally beneficial with knowledge sharing. Knowledge sharing alone was not enough, but it was better if through the quality of work-life than directly to ASN performance (more complete results presented in Table 3).

The third conceptual model in testing the hypothesis is shown in Table 3 . It the training was measured with technical training indicators and others training it would provide findings that were relatively like the first model, where knowledge sharing had no significant effect on ASN Performance $(C R=1,645 ; \mathrm{P}=0.100)$. Other findings provided the same implications: training had a significant effect on knowledge sharing $(C R=3.353 ; \mathrm{P}=0.000)$, then knowledge sharing had a significant effect on quality of work-life $(C R=6.809 ; \mathrm{P}=0,000)$, and quality of work-life had an effect significant on ASN Performance $(C R=5,018 ; \mathrm{P}=0,000)$. Others have confirmed that the more training conducted by ASN, the greater opportunity to do a lot of knowledge sharing (Freeze \& Kulkarni, 2007). In addition, training improves employee skills, which can further improve performance (Cooper, 2006).

\section{Conclusion}

These findings revealed some interesting things for improving as performance. First, the role of leadership training and other training as a measuring tool for training in an effort to increase knowledge sharing was very influential compared to functional training and other training or technical training and other training. Second, even though leadership training and other training had a large impact on increasing knowledge sharing, this was unable to improve 
the quality of work-life and ASN performance. In fact, if ASN wanted the quality of work-life to increase, then what needs to be considered is maximising the functional training program. Third, the three conceptual models showed that the indirect effect of knowledge sharing on ASN performance was better than the direct impact. So, the way to improve ASN performance, quality of work-life was really needed in the three conceptual models. The results of this study confirm that to maximise the ability of the state civil apparatus, knowledge sharing has a crucial role, especially when accompanied by the quality of work life. Thus, with the same training costs, if knowledge sharing and quality of work life are boosted, the performance of the civil service can be improved. These results answer concerns so far that the training conducted to ASNs at such a high cost can contribute to improving their performance during knowledge sharing and quality of work life is also optimal.

1. Knowledge management gives birth to innovations that will place the government as a learning organization.

2. Each civil servant can share all the knowledge they have to be disseminated to other employees.

3. Attitudes that must be cultivated and cultivated information of knowledge management systems, including encouragement strong to create, capture, process, and disseminate the knowledge they have to other employees.

4. To build a creative, innovative, and willing to share knowledge culture, it is necessary to be supported by adequate technology and compensation as an appreciation for the efforts made by civil servants.

5. Building a knowledge sharing culture is a process that is carried out continuously and consistently.

6. The formation of a knowledge-sharing culture encourages creativity in expertise and innovation to improve civil servants' performance.

\section{References}

A, M. A., Siraj, M. L., \& Yusriadi, Y. (2019). The effectiveness of the implementation of independent community empowerment programs in Bone District. International Journal of Scientific \& Technology Research, 8(8). https://www.ijstr.org/finalprint/aug2019/The-Effectiveness-Of-The-Implementation-Of-Independent-

Community-Empowerment-Programs-In-Bone-District.pdf

Alavi, M., \& Leidner, D. E. (2001). Review: Knowledge management and knowledge management systems: Conceptual foundations and research issues. MIS Quarterly: Management Information Systems. https://doi.org/10.2307/3250961

Byrne, B. M. (2013). Structural equation modeling with AMOS. In Structural Equation Modeling With AMOS. https://doi.org/10.4324/9781410600219

Cabrera, Á., \& Cabrera, E. F. (2002). Knowledge-sharing dilemmas. Organization Studies. https://doi.org/10.1177/0170840602235001

Cooper, C. (2006). Knowledge management and tourism. Annals of Tourism Research. https://doi.org/10.1016/j.annals.2005.04.005

Dalkir, K. (2011). Knowledge management. Understanding Information Retrieval Systems: Management, Types, and Standards. https://doi.org/10.4018/jksr.2012070105

Darroch, J. (2005). Knowledge management, innovation and firm performance. Journal of Knowledge Management. https://doi.org/10.1108/13673270510602809

Davenport, T., De Long, D., \& Beers, M. (1998). Successful Knowledge Management Projects. Sloan Management Review.

Denhardt, R. B., \& Denhardt, J. V. (2000). The new public service: Serving rather than steering. 
Public Administration Review. https://doi.org/10.1111/0033-3352.00117

Earl, M. (2001). Knowledge management strategies: Toward a taxonomy. Journal of Management Information Systems. https://doi.org/10.1080/07421222.2001.11045670

Ermine, J. L. (2010). Introduction to Knowledge Management. Trends in Enterprise Knowledge Management. https://doi.org/10.1002/9780470612132.ch1

Freeze, R. D., \& Kulkarni, U. (2007). Knowledge management capability: Defining knowledge assets. Journal of Knowledge Management. https://doi.org/10.1108/13673270710832190

Gagné, M. (2009). A model of knowledge-sharing motivation. Human Resource Management. https://doi.org/10.1002/hrm.20298

Gao, F., Meng, M., \& Clarke, S. (2008). Knowledge, management, and knowledge management in business operations. Journal of Knowledge Management. https://doi.org/10.1108/13673270810859479

Gennaioli, N., La Porta, R., Lopez-de-Silanes, F., \& Shleifer, A. (2013). Human capital and regional development. Quarterly Journal of Economics. https://doi.org/10.1093/qje/qjs050

Gold, A. H., Malhotra, A., \& Segars, A. H. (2001). Knowledge management: An organizational capabilities perspective. Journal of Management Information Systems. https://doi.org/10.1080/07421222.2001.11045669

Hansen, M. T., Mors, M. L., \& Løvås, B. (2005). Knowledge sharing in organizations: Multiple networks, multiple phases. Academy of Management Journal. https://doi.org/10.5465/AMJ.2005.18803922

Hasbi, Sukimi, M. F., Latief, M. I., \& Yusriadi, Y. (2019). Compromise in traditional ceremonies: A case study of the Rambu solo' ceremony in Toraja regency. Humanities and Social Sciences Reviews, 7(6), 286-291. https://doi.org/10.18510/hssr.2019.7651

Hasbi, Tang, M., Sukimi, M. F., Wibowo, A. D., \& Yusriadi. (2020). Utilization of natural resources and social security in fishermen families on Salemo Island and West Rangas, South Sulawesi Province. Humanities and Social Sciences Reviews. https://doi.org/10.18510/hssr.2020.8280

Hyland, P., \& Soosay, C. (2008). Innovation, technology and knowledge management. Operations Management: An Integrated Approach. https://doi.org/10.1017/CBO9781139150002.009

Inkpen, A. C., \& Tsang, E. W. K. (2005). Social capital networks, and knowledge transfer. Academy of Management Review. https://doi.org/10.5465/AMR.2005.15281445

Kamaşak, R., \& Bulutlar, F. (2010). The influence of knowledge sharing on innovation. European Business Review. https://doi.org/10.1108/09555341011040994

Kilinc, E. (2014). Pre-service social studies teachers' understandings about the nature of the social studies. International Electronic Journal of Elementary Education, 6(3), 415426.

Kilinc, E. (2017). Review of Modernising School Governance: Corporate Planning and Expert Handling in State Education. Research in Social Sciences and Technology, 2(2), 76-90.

Lord, P. (2006). Sharing knowledge. Journal of Medical Marketing: Device, Diagnostic and Pharmaceutical Marketing. https://doi.org/10.1057/palgrave.jmm.5050023

McInerney, C. (2002). Knowledge management and the dynamic nature of knowledge. Journal of the American Society for Information Science and Technology. https://doi.org/10.1002/asi.10109

Houdyshell, M., \& Kirk, P. (2018). Graduate students' perceptions' on a professional pathway for academic advisors. American Journal of Qualitative Research, 2(1), 77-96.

Miller, L. (2018). Social Networking Strategy for Creating Public Value in Eastern India. Journal of Ethnic and Cultural Studies, 5(1), 85-93. http://dx.doi.org/10.29333/ejecs/97 
Moenir, H. A. S. (2010). Manajemen Pelayanan Umum di Indonesia. Manajemen Pelayanan Umum Di Indonesia. https://doi.org/2010

Mustafa, D., Farida, U., \& Yusriadi, Y. (2020). The effectiveness of public services through egovernment in Makassar City. International Journal of Scientific \& Technology Research, 9(1). http://www.ijstr.org/final-print/jan2020/The-Effectiveness-Of-PublicServices-Through-E-government-In-Makassar-City.pdf

Nguyen, D. (2020). Asian American Women in the Academy: Multiple Success Case Study of their Leadership Labyrinths and Practices. American Journal of Qualitative Research, 4(3), 14-44. https://doi.org/10.29333/ajqr/8467

Peña, C., Jones, L., Orange, A., Simieou, F., \& Márquez, J. (2018). Academic success and resiliency factors: A case study of unaccompanied immigrant children. American Journal of Qualitative Research, 2(1), 161-181.

Peters, B. G., \& Peters, B. G. (2018). The Politics of Bureaucracy. In The Politics of Bureaucracy. https://doi.org/10.4324/9781315813653-5

Phelps, C., Heidl, R., \& Wadhwa, A. (2012). Knowledge, networks, and knowledge networks: A Review and research agenda. Journal of Management. https://doi.org/10.1177/0149206311432640

Rahawarin, M. A., Zacharias, T., Yusriadi, Y., \& Rianti, M. (2020). Dimension of organizational citizenship behavior and its effect toward employees' performance at capital investment and licensing service office South Buru District. Humanities and Social Sciences Reviews. https://doi.org/10.18510/hssr.2020.8276

Ramseook-Munhurrun, P., Lukea-Bhiwajee, S., \& Naidoo, P. (2010). Service Quality in the Public Service. International Journal of Management and Marketing Research.

Rijal, S., Haerani, Y., Mayasari, R. E., \& Yusriadi, Y. (2019). The effectiveness of implementation of government regulation number 41 the year 2011 on the development of youth entrepreneurship and pioneering and the provision of youth facilities and infrastructures in Kolaka. International Journal of Scientific \& Technology Research, 8(10). http://www.ijstr.org/paper-references.php?ref=IJSTR-1019-22680

Rowley, J. (1999). What is knowledge management? Library Management. https://doi.org/10.1108/01435129910291175

Rubenstein-Montano, B., Liebowitz, J., Buchwalter, J., McCaw, D., Newman, B., \& Rebeck, K. (2001). A systems thinking framework for knowledge management. Decision Support Systems. https://doi.org/10.1016/S0167-9236(00)00116-0

Ruslan, Rosady, S. H. M. (2014). Manajemen public relations \& Media Komunikasi. Manajemen Public Relations \& Media Komunikasi.

Sri Wahyu Lelly Hana Setyanti, S. W. L. H. S. (2013). Innovation role in mediating the effect of entrepreneurship orientation, management capabilities and knowledge sharing toward business performance: Study at Batik SMEs in East Java Indonesia. IOSR Journal of Business and Management. https://doi.org/10.9790/487x-0841627

Teece, D. J., Pisano, G., \& Shuen, A. (2009). Dynamic capabilities and strategic management. Knowledge and Strategy. https://doi.org/10.1142/9789812796929_0004

Umar, A., Amrin, Madani, M., Farida, U., Yusriadi, Y., Tamsa, H., Bahtiar, Ansar, Yahya, M., Nurnaningsih, Alam, S., Gunawan, H., Darwis, Sahabuddin, C., Jamaluddin, Misbahuddin, Elpisah, Akbar, Z., Sakkir, G., ... Misnawati, M. (2019). One-stop service policy as a bureaucratic reform in Indonesia. Academy of Strategic Management Journal, 18(2), 1-12.

Umar, A., Hasbi, Farida, U., \& Yusriadi, Y. (2019). Leadership role in improving responsibility of employee's work in scope of general bureau of government of bulukumba regency. International Journal of Scientific and Technology Research, 8(10), 2019-2021.

Van De Ven, A. H., \& Johnson, P. E. (2006). Knowledge for theory and practice. Academy of 
Management Review. https://doi.org/10.5465/amr.2006.22527385

Xue, Y., Bradley, J., \& Liang, H. (2011). Team climate, empowering leadership, and knowledge sharing. Journal of Knowledge Management. https://doi.org/10.1108/13673271111119709

Yusriadi, Sahid, A., Amirullah, I., Azis, A., \& Rahman, A. A. (2019). Bureaucratic reform to the human resouces: A case study on the one-stop integrated service. Journal of Social Sciences Research, 5(1), 61-66. https://doi.org/10.32861/jssr.51.61.66

\section{Notes on Contributors}

Hasmin Tamsah: Head of the master management study program and lecturer at Sekolah Tinggi Ilmu Ekonomi Amkop. Doctorate in economics and has published several papers at the national and international levels-identity at https://orcid.org/0000-0002-95709658 and Scopus ID 5720744971.

Ansar: Professor in economics, a graduate lecturer at Sekolah Tinggi Ilmu Ekonomi Amkop, secretary of the human resource development unit at the Higher Education Service Institute in Region IX. He has several publications at the national and international level.

Gunawan: Chairman of the Institute for Research and Community Service, Assistant Director for finance, and lecturer at Sekolah Tinggi Ilmu Ekonomi Amkop. Doctorate in economics and has several publications at the national and international levels.

Yusriadi Yusriadi: Head of the Sekolah Tinggi Ilmu Hukum Pengayoman, also a lecturer at the Sekolah Tinggi Ilmu Administrasi Puangrimaggalatung. Doctorate in public administration and has published several papers at the national and international levels, 2020 as the recipient of community service grants from the Ministry of Education and Culture, Ministry of Research and Technology/National Research and Innovation Agency Republic Indonesia.

Umi Farida: Lecturer at Sekolah Tinggi Ilmu Ekonomi AMKOP, administrator of the human resource development unit at the Higher Education Service Institute in Region IX. Doctorate in public administration and has published several papers at the national and international levels. 